ELORE (ISSN 1456-3010), vol. 16 - 2/2009.

Julkaisija: Suomen Kansantietouden Tutkijain Seura ry.

[http://www.elore.fi/arkisto/2_09/kirjallisuus_tuuva-hongisto_2_09.pdf]

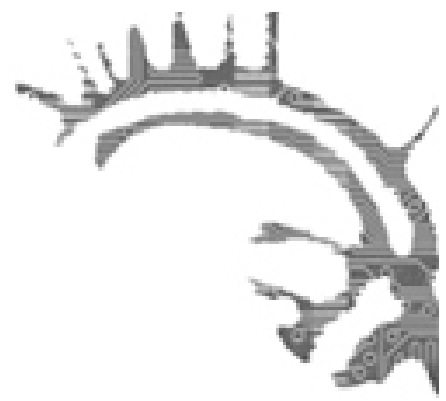

\title{
KIRJA-ARVIO:
}

\section{Kuluttajien taikamaAilma}

Ilmonen, Kaj 2007: Johan on markkinat. Kulutuksen sosiologista tarkastelua. Tampere: Vastapaino. 431 sivua.

\section{$\underline{\text { Sari Tuuva-Hongisto }}$}

Kaj Ilmonen on Johan on mark.kinat-teoksensa esipuheessa harmissaan kulutussosiologian heikosta asemasta työelämään liittyvän tutkimuksen puristuksessa, vaikka talouden kasvu on hyvinkin riippuvaista kulutuksesta. Ilmosen huoli kulutuksen asemasta ei ehkä ole enää niin aiheellista nyt pari vuotta kirjan julkaisemisen jälkeen. Kulutuksen sekä kulutustutkimuksen merkitys on vahvistunut ja kulutus tuntuu olevan esillä yhä enemmän ja merkittävämmässä roolissa. Kuluttamisen katsotaan olevan tie lamasta, kulutusta ei pitäisi vähentää eikä sen merkitystä väheksyä. Yhä enemmän talouden kasvua haetaan kuluttajien tarpeista ja tuotesuunnittelussa nostetaan esiin kuluttajalähtöisyys ja uudenlaiset bisnesmallit. Vihreä kuluttajuus tai eettinen kuluttajuus ovat tuotteiden ja palveluiden suunnittelussa huomioitavia näkökulmia. Kuluttamista viimeaikaiseen keskusteluun ovat nostaneet muun muassa Roope Mokka ja Aleksi Neuvonen (2009) pamfletissaan, jossa kuluttaminen nousee maailman muutoksen keskeiseksi elementiksi ja kulutuskäyttäytymisen muutos välttämättömäksi tulevaisuuteen sijoittuvissa skenaarioissa. Kulutuksen korostuessa myös kulutustutkimuksen ja kulutusta selittävien tekijöiden tunnistaminen ja tunteminen ovat yhä tärkeämpiä.

Kulutussosiologian ja kulutuksen tutkimuksen merkityksen voi siis katsoa voimistuneen viime vuosina ehkä erityisesti näkökulman ja painotusten muutosten myötä: innovaatiotutkimus ja käyttäjätutkimus ovat nostaneet käyttäjän ja kuluttajan näkökulman yhä keskeisemmäksi. Kokemustalouden tai elämystalouden keskustelut lähtevät liikkeelle tuotantopainotteisuuden sijasta kuluttajien elämyksistä ja osallistuvasta suunnittelusta. Yhä useampi elämänalue kuuluu kulutuksen piiriin, kuten kirjan takakannessakin luvataan. 


\section{SARI TUUVA-HONGisto}

\section{KULUTUSSOSIOLOGIAN KÄSIKIRJA}

Johan on markkinat-kirjaa voi pitää kulutussosiologian käsikirjana. Sivuja on yli 400 ja päälukujakin kaksitoista. Luvuissa käsitellään niin kulutussosiologian historiaa, markkinoita, halua, taloutta, rahaa, kuluttajavalintoja, ideologiaa, lahjoja kuin politiikkaakin. Kirjan markkinoilla liikkuvat sekä yritykset, tavarat, raha että kuluttajat. Sen parasta antia on laaja kulutuksen sosiologian historian yhteenveto sekä kulutuksen keskeisten osatekijöiden erittely ja oppihistoriallinen taustoitus.

Johan on markkinat on siis selkeä perusteos, ja se antaa hyvän käsityksen kulutuksesta sosiologisena kysymyksenä. Kirja vetää yhteen teoreettista keskustelua ja kulutuksen tarkastelun lähestymistapoja. Sen keskeisenä fokuksena ovat markkinat ja kulutuksen politisoituminen. Toisaalta kirjassa myös tuodaan esiin viime vuosien kulutuksen merkitysten ja elämyksellisyyden sekä hedonistisen kulutuksen näkökulmia. Ilmonen osoittaa, että markkinatutkimusten sijaan mielenkiinto on suuntautumassa kulutuksen kokemukselliseen puoleen ja samalla esineiden ja ihmisten suhteeseen. Tämä avaa näkökulmia siihen, miten yksilöllinen ja yhteinen rakentuvat kulutuksen välityksellä. Merkityspainotteista kulutustutkimusta Ilmonen hahmottaa etsimällä sille juuria antropologiasta ja lahjataloudesta, jonka perillisiksi uudet merkityspainotteiset ja tulkinnalliset näkökulmat asettuvat.

\section{KulUtussosIOLOGIAN KÄSIKIRJA II}

Kirja on uusintateos jo klassikoksi muodostuneesta saman kirjoittajan Tavaroiden taikamaailmasta, joka on julkaistu vuonna 1993. Kirja ei ole uusintapainos mutta ei myöskään täysin itsenäinen uutuusteos. Johan on markkinat on täydennetty ja päivitetty versio Tavaroiden taikamaailmasta, mutta jäin väistämättä epäilemään, voiko kirjaa lukea itsenäisenä kirjana. Kirjassa palataan alkuperäisteokseen usein sekä kommentoidaan ja muutetaan siinä tehtyjä tulkintoja. Välillä jäin miettimään, kumpaa Kaj Ilmosta uskoisin.

Esipuheessa Ilmonen valottaa valintoja näin: " - - kirjan painopisteet asettuvat toisella tavalla kuin Taikamaailmassa. Jos tavara ja valinta olivat siinä keskeisiä, nyt olen halunnut nostaa niiden rinnalle sellaisia kehyksiä, joissa tavara liikkuu ja valinnat toteutuvat" (s. 12). Suurin piirtein samanlaisia ovat tavaran ulottuvuuksia käsittelevä jakso ja rahaa käsittelevä luku, mutta muihin lukuihin on tehty lisäyksiä ja uusia jäsennyksiä.

Ilmonen tuo siis tässä kirjassa esiin erityisesti markkinoiden merkitystä ja pitää tärkeänä, ettei markkinoiden käsittelyä pidä jättää vain taloustieteilijöiden alueeksi. Toinen uutuus kirjassa on lahjatalous Marcell Maussia seuraten. Lahjan käsittely, vaikkakin perusteellisena ja kiinnostavana, jää kuitenkin kirjan kokonaisuudessa irralliseksi.

Kuluttajanäkökulma, käyttäjälähtöisyys, asiakaslähtöisyys ovat olleet viime vuosina yhä keskeisempiä uuden kehittämisen avainsanoja. Näiden näkökulmien nousemisen pohjaksi suomalaisen kulutussosiologian pioneerin Kaj Ilmosen Joban on markkinat antaa oivallisen perustietopaketin siitä, mitä kulutus on sosiologisena ilmiönä. Johan on markkinat jäi Kaj Ilmosen viimeiseksi teokseksi. Hän menehtyi pian kirjan julkaisemisen jälkeen. 
KULUTTAJIEN TAIKAMAAILMA

\section{KIRJALlisuUS}

ILMONEN, KAJ 1993: Tavaroiden taikamaailma. Sosiologinen avaus kulutukseen. Tampere: Vastapaino.

MOKKA, ROOPE \& NEUVONEN, ALEKSI (toim.) 2009: Olimme kuluttajia. Neljä tarinaa vnodesta 2023. Helsinki: Tammi.

Filosofian tohtori Sari Tuuva-Hongisto työskentelee kehittämisasiantuntijana Metsäalan ennakointiyksikössä Joensuun yliopistossa. 